\title{
26. ALKENONES IN SEDIMENTS OF MIDDLE VALLEY, LEG 139: APPLICATION AS THERMAL SENSORS ${ }^{1}$
}

\author{
Bernd R.T. Simoneit, ${ }^{2}$ F.G. Prahl, ${ }^{2}$ R.N. Leif, ${ }^{2}$ and S.-Z. $\mathrm{Mao}^{3}$
}

\begin{abstract}
The shallow sections of most holes drilled during Ocean Drilling Program Leg 139 contain alkenones derived from prymnesiophyte algae. The alkenones indicate a paleotemperature of the photic zone in the upper ocean during primary carbon fixation of $7^{\circ}-15^{\circ} \mathrm{C}$, with an average of $10.7^{\circ} \mathrm{C}$. Based on laboratory hydrous pyrolyses these alkenones are altered to unknown products around $200^{\circ} \mathrm{C}$ and are thus useful as thermal probes. The disappearance of the alkenones occurs at various depths below seafloor in accordance with observed heat flows.
\end{abstract}

\section{INTRODUCTION}

Molecular stratigraphy utilizes specific organic compounds (biomarkers) with distinct biological origins to characterize sedimentary sequences (Brassell et al., 1986; Farrimond et al., 1990a). One such class of biomarkers is a group of long-chain (C37 to C39) alkenones. These compounds elute late in the gas chromatograms of the bitumen extracts, generally without interference from other compounds and are resolved into three peak clusters (Sikes and Volkman, 1993, and references therein). These alkenones are widespread in Quaternary marine sediments and preserve a record of past sea-surface temperature (Marlowe et al., 1990; Brassell et al., 1986). They are derived primarily from prymnesiophyte algae such as Emiliania huxleyi (e.g., Marlowe et al., 1990; Volkman et al., 1980), in which the degree of alkenone unsaturation, expressed as an index $\left(\mathrm{U}_{37}^{\mathrm{K}}=[37: 2] /([37: 2]+\right.$ [37:3])), is linear vs. the growth temperature determined by laboratory culture experiments with Emiliania huxleyi and field correlations (Prahl and Wakeham, 1987; Sikes and Volkman, 1993).

These alkenones were found in sediments from Middle Valley recovered during Ocean Drilling Program (ODP) Leg 139 (Davis, Mottl, Fisher, et al., 1992). This study confirms the molecular identity of these compounds by mass spectrometry, assigns a temperature scale to the $U_{37}^{K}$ index based on current calibration curves for the source algae, and evaluates the thermal stability of these compounds vs. depth below seafloor in a hydrothermal system so that they may be applied as geothermal probes.

Middle Valley, a northern segment of the Juan de Fuca Ridge, is a sedimented spreading center over zero-aged crust with limited discharge of hydrothermal fluids. Four sites were drilled during Leg 139 in four distinct hydrologic environments (Fig. 1), all within $5 \mathrm{~km}$ of each other. Site 855 represents the recharge area at the eastern fault boundary of the rift, Site 856 is in a relict sulfide deposit, at Site 857 the scientific party attempted to sample the hydrothermal reservoir, and Site 858 is in the active hydrothermal vent region (Davis, Mottl, Fisher, et al., 1992). All sediments analyzed here are of Pleistocene age.

\section{EXPERIMENTAL METHODS}

Initial screening of sediment extracts for alkenones was carried out on board the JOIDES Resolution using the solvent supernatant

\footnotetext{
${ }^{1}$ Mottl, M.J., Davis, E.E., Fisher, A.T., and Slack, J.F. (Eds.), 1994. Proc. ODP, Sci. Results, 139: College Station, TX (Ocean Drilling Program).

${ }^{2}$ College of Oceanic and Atmospheric Sciences, Oregon State University, Corvallis, OR 97331 , U.S.A.

${ }^{3}$ Department of Geology, Florida State University, Tallahassee, FL 32306, U.S.A (Current address: Beijing Graduate School, Department of Geology, China University of Geosciences, Xueyuan Road 29, 100083 Beijing, People's Republic of China.)
}

from the fluorescence extraction, which was removed and concentrated for analysis (Davis, Mottl, Fisher, et al., 1992). Additional wet sediments were extracted both on board and in the laboratory with methanol $/ n$-hexane (1:2) by shaking, subsequent centrifugation (2000 rpm), and removal of the hexane supernatant, leaving behind the methanol/water phase. Freeze-dried sediment samples were ground gently in an agate mortar, and about $500 \mathrm{mg}$ of each was weighed out and transferred into 1-dram screw-capped vials for similar extraction. Hexane $(2 \mathrm{~mL})$ was added and the suspension was heated at $60^{\circ} \mathrm{C}$ in a water bath and shaken occasionally for $2 \mathrm{hr}$. The clear supernatant solution was pipetted into a second vial and the extraction was repeated with another $1-\mathrm{mL}$ aliquot of hexane. Combined extracts were evaporated under nitrogen blow-down at $30^{\circ} \mathrm{C}$ to volumes of 10 to $40 \mu \mathrm{L}$. A 1- to 3- $\mu \mathrm{L}$ sample was then injected into the gas chromatograph (GC) or GC-mass spectrometer (MS) using normal protocol. The alkenones were identified by comparison of the retention times with prior data and in the laboratory with authentic standards and confirmation by GC-MS. The final results are based on the ratio of the relative $\mathrm{C}_{37}$ alkadienone and $\mathrm{C}_{37}$ alkatrienone concentrations as determined from high-resolution GC and GC-MS (total ion current signal). The total $\mathrm{C}_{37}$ alkenones are also reported as a ratio relative to $n-\mathrm{C}_{29} \mathrm{H}_{60}$.

Hydrous pyrolysis was carried out for the alkenone alteration (Leif et al., 1991, 1992). A 250-mL stainless steel vessel (Parr Instrument T316SS) equipped with a thermocouple for temperature control $\left( \pm 2^{\circ} \mathrm{C}\right)$ and a gage block assembly for recovery of volatile compounds was used for the reactions. Conditioning of the vessel prior to each experiment was done by heating it with $63.5 \mathrm{~mL}$ of water at $350^{\circ} \mathrm{C}$ for $24 \mathrm{hr}$. For each experiment $10 \mathrm{~g}$ of sediment and $63.5 \mathrm{~mL}$ of deoxygenated water (bubbled with $\mathrm{N}_{2}$ to degas) were combined in the reaction vessel. Assembly of the reaction vessel was done in a glove bag under a nitrogen atmosphere. The vessel was then placed in a heater and the temperature was maintained at $200^{\circ}, 250^{\circ}, 300^{\circ}$, and $350^{\circ} \mathrm{C}$, respectively, for $24 \mathrm{hr}$ each. The vessel was cooled to room temperature before opening after each run and the contents were transferred to a separatory funnel. The interior of the vessel was rinsed with methanol and methylene chloride, which were added to the separatory funnel, and the organic fraction was separated. The water was extracted with two additional $20-\mathrm{mL}$ portions of methylene chloride. The organic fractions were combined and concentrated. The products were fractionated by column chromatography (Kawka and Simoneit, 1987) into three fractions. The alkenones were eluted in fraction 2 .

The GC aboard ship is a Hewlett-Packard Model 5890A, fitted with a $30 \mathrm{~m} \times 0.25 \mathrm{~mm}$ capillary column coated with DB-1 $(1.0 \mu \mathrm{m}$ film thickness). The temperature was programmed as isothermal for $3 \mathrm{~min}$ at $30^{\circ} \mathrm{C}, 10^{\circ} \mathrm{C} / \mathrm{min}$ to $220^{\circ} \mathrm{C}, 4^{\circ} \mathrm{C} / \mathrm{min}$ to $300^{\circ} \mathrm{C}$, and isothermal for $15 \mathrm{~min}$, with the injector at $250^{\circ} \mathrm{C}$, flame ionization detector (FID) at $300^{\circ} \mathrm{C}$, and helium as the carrier gas. The GC in the laboratory is 


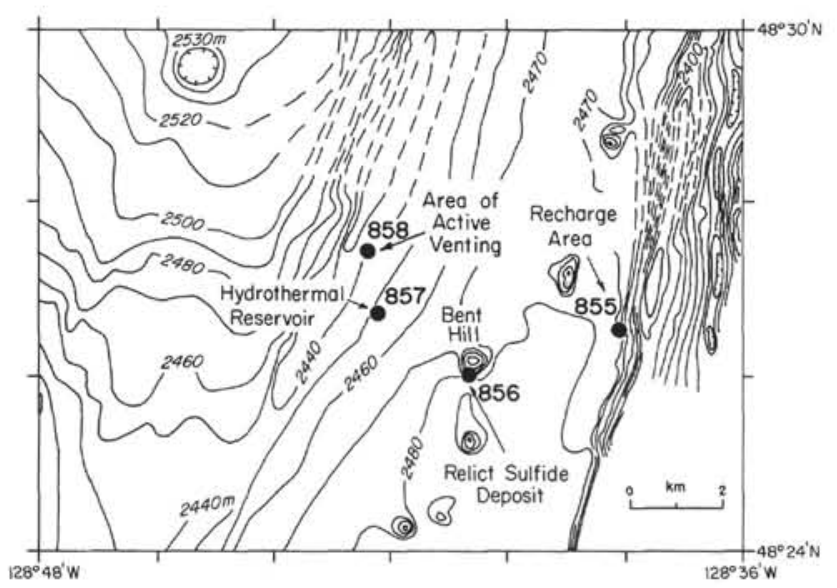

Figure 1. Location map of the Leg 139 drill sites in Middle Valley, northeast Pacific. Bathmetry in meters.

also a Hewlett-Packard Model 5890A equipped with a $30 \mathrm{~m} \times 0.25$ $\mathrm{mm}$ capillary column coated with DB- $5(0.25 \mu \mathrm{m}$ film thickness $)$. The $\mathrm{GC}$ oven temperature was programmed from $65^{\circ} \mathrm{C}$ (hold for $2 \mathrm{~min}$ ) to $310^{\circ} \mathrm{C}$ at $4^{\circ} \mathrm{C} / \mathrm{min}$ and isothermal for $30 \mathrm{~min}$, with the injector at $290^{\circ} \mathrm{C}$, FID at $325^{\circ} \mathrm{C}$, and $\mathrm{He}$ as the carrier gas.

Analyse by GC-MS were carried out with a Finnigan Model 9610 gas chromatograph coupled to a Finnigan Model 4021 quadrupole mass spectrometer operated at $70 \mathrm{eV}$ over the mass range 50-650. The GC was fitted with an identical column to the one described above for the analytical GC, and the same temperature program and operating conditions as for the laboratory GC described above were used. The GC-MS data were acquired and processed with an on-line Finnigan-Incos Model 2300 computer data system.

\section{RESULTS AND DISCUSSION}

The alkenone unsaturation index $\left(\mathrm{U}_{37}^{K}\right)$ was calculated for these samples after confirmation of the compound composition by GC-MS. The index is based on the expression (Brassell et al., 1986):

$$
\mathrm{U}_{37}^{\mathrm{K}}=\left[\mathrm{C}_{37: 2}\right] /\left(\left[\mathrm{C}_{37: 2}\right]+\left[\mathrm{C}_{37: 3}\right]\right) .
$$

The calibration curve used is that tested by Prahl and Wakeham (1987) and further extended by extrapolation to colder waters in the Southern Ocean by Sikes and Volkman (1993). The data were converted to temperature estimates using the calibration equation: $U_{37}^{K}=$ $0.042 \mathrm{~T}-0.164$ (Sikes and Volkman, 1993). The relative concentrations of the $\mathrm{C}_{37}$ alkenones (sum of $\mathrm{C}_{37: 2}+\mathrm{C}_{37: 3}$ ) were also compared to the concentration of $n$-nonacosane, which is a conservative alkane into the organic matter maturation window for the Middle Valley hydrothermal system. The even $n$-alkane concentrations increase and the odd $n$-alkane concentrations generally remain constant relative to the total extract yield as the temperature rises during maturation (Simoneit, this volume). Therefore, the assumption that $n$-nonacosane is conservative is reasonable in the absence of absolute quantitation. Thus, the decrease in the alkenone/alkane ratio, that is,

$$
\frac{\left[n-\mathrm{C}_{29} \mathrm{H}_{60}\right]+[\Sigma 37: \mathrm{i}]}{\left[n-\mathrm{C}_{29} \mathrm{H}_{60}\right]},
$$

from high values $(\sim 6)$ to unity, reflects the decrease in the relative $\mathrm{C}_{37}$ alkenone concentrations (Davis, Mottl, Fisher, et al., 1992). The results are listed in Table 1.

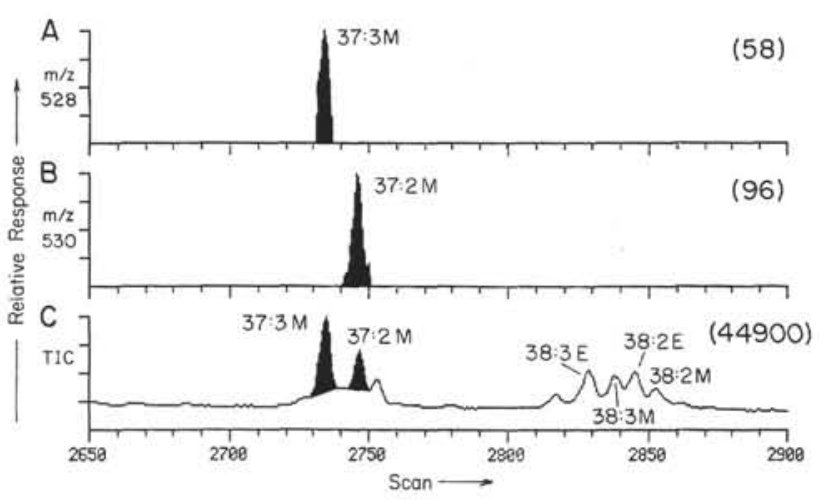

Figure 2. Example of partial GC-MS data for the $\mathrm{C}_{37}$ and $\mathrm{C}_{38}$ alkenones in Sample 139-858D-1H-1, $0 \mathrm{~cm}$. A. m/z 528 molecular weight of $\mathrm{C}_{37}$ methylalkatrienone. B. $\mathrm{m} / \mathrm{z} 530$ molecular weight of $\mathrm{C}_{37}$ methylalkadienone. C. Total ion current trace ( $37: 3 \mathrm{M}=\mathrm{C}_{37}$ methylalkatrienone, $37: 2 \mathrm{M}=\mathrm{C}_{37}$ methylalkadienone, $38: 3 \mathrm{E}=\mathrm{C}_{38}$ ethylalkatrienone, $38: 3 \mathrm{M}=\mathrm{C}_{38}$ methylalkatrienone, $38: 2 \mathrm{E}$ $=\mathrm{C}_{38}$ ethylalkadienone, $38: 2 \mathrm{M}=\mathrm{C}_{38}$ methylalkadienone). Relative ion intensity is given in parentheses.

An example of the salient features of the GC-MS data for the alkenones is shown in Figure 2. The molecular ion intensities of the $\mathrm{C}_{37}$ alkatrienone $(\mathrm{m} / \mathrm{z} 528)$ and the $\mathrm{C}_{37}$ alkadienone $(\mathrm{m} / \mathrm{z} 530)$ are plotted, and these coincide with the two dominant peaks in the total ion current trace. The mass spectra of these two compounds match the fragmentation patterns of the published standards (Rechka and Maxwell, 1988a, 1988b) and also match the same compounds isolated from Emiliania huxleyi cultures (K. Amthor, unpubl. data).

The thermal stability of the alkenones has been examined by hydrous pyrolysis of immature seabed sediments from Guaymas Basin, Gulf of California, at discrete temperatures. In the first hydrous pyrolysis series, only temperature was varied and not time, which remains for future experiments. The $U_{37}^{K}$ index of the starting sediment is 0.81 , and after heating at $200^{\circ} \mathrm{C}$ the ratio is 0.69 , showing preferential alteration of the alkenones to unknown products. The ratio of the relative concentrations of the sum of $\mathrm{C}_{37: 2}+\mathrm{C}_{37: 3}$ alkenones to $n$ - nonacosane (Table 1) decreases in the $200^{\circ} \mathrm{C}$ experiment, indicating loss of the alkenones. The alkenones are not detectable in the products from the hydrous pyrolysis at $250^{\circ} \mathrm{C}$, indicating their complete thermal alteration between $200^{\circ}$ and $250^{\circ} \mathrm{C}$. Because the hydrothermal alteration of organic matter in sedimented rifts is a rapid process (Simoneit, 1990, 1991; Simoneit et al., 1992; Peter et al., 1991), these laboratory simulations should closely mimic the natural systems. Thus, the in-situ temperature in the sediments where these alkenones disappear at depth could have approached a maximum of about $200^{\circ} \mathrm{C}$ for a brief time interval, or based on the present in-situ temperatures (Table 2), the alkenones were altered at lower temperatures $\left(20^{\circ}-80^{\circ} \mathrm{C}\right)$ over longer time periods (hundreds of years).

\section{Site 855}

The $U_{37}^{K}$ index for the samples from Site 855, the off-axis recharge area, range from 0.13 to 0.46 (Table 1, Fig. 3A), equivalent to a growth temperature range from $7^{\circ}$ to $15^{\circ} \mathrm{C}$ overall and $6^{\circ}$ to $8^{\circ} \mathrm{C}$ in the deeper sections (85-110 mbsf). Using the same calibration of Sikes and Volkman (1993) growth temperatures estimated from index measurements made with depth in a sediment core collected $\sim 6^{\circ}$ of latitude farther south beneath the California Current (at $42^{\circ} \mathrm{N}$, $127^{\circ} \mathrm{W}$ ) are $\sim 15^{\circ} \mathrm{C}$ for the intervals from the present to the interglacial period and decline to $\sim 11^{\circ} \mathrm{C}$ for intervals from the past glacial period $\left(\mathrm{U}_{37}^{\mathrm{K}}: 0.30-0.45\right.$; Prahl, unpubl. data). The alkenone/alkane plots for these holes show a general depletion of alkenones vs. depth (Fig. 4A), indicating invasion by higher temperature fluids in the past (i.e., from sill intrusions). 
Table 1. Alkenone unsaturation index vs. sub-bottom depth for sediments from Leg 139.

\begin{tabular}{|c|c|c|c|c|}
\hline $\begin{array}{l}\text { Core, section, } \\
\text { interval (cm) }\end{array}$ & $\begin{array}{r}\text { Depth } \\
\text { (mbsf) }\end{array}$ & $\mathrm{U}_{37}^{\mathrm{K}}$ & $\frac{\left[n-\mathrm{C}_{29} \mathrm{H}_{60}\right]+[\Sigma 37: \mathrm{i}]^{\mathrm{a}}}{\left[n-\mathrm{C}_{29} \mathrm{H}_{60}\right]}$ & $\begin{array}{c}\text { Emiliania } \\
\text { huxleyi }^{\mathrm{b}} \\
\text { presence }^{\mathrm{b}}\end{array}$ \\
\hline \multicolumn{5}{|l|}{ 139-855A- } \\
\hline $1 \mathrm{R}-1,77-79$ & 0.8 & 0.32 & 1.61 & $\mathrm{~F}$ \\
\hline $4 \mathrm{R}-3,31-33$ & 29.3 & 0.31 & 2.86 & $\mathrm{R}$ \\
\hline $7 \mathrm{R}-3,43-46$ & 58.6 & 0.46 & 2.27 & F \\
\hline \multicolumn{5}{|l|}{ 139-855B- } \\
\hline $4 \mathrm{R}-3,99-102$ & 28.5 & 0.33 & 1.30 & $\mathrm{R}$ \\
\hline $6 \mathrm{R}-1,25-29$ & 44.2 & n.d. & 1.00 & $\mathrm{R}$ \\
\hline \multicolumn{5}{|l|}{$139-855 \mathrm{C}$} \\
\hline $1 \mathrm{R}-1,66-69$ & 0.7 & 0.27 & 1.20 & $\mathrm{~F}$ \\
\hline $1 \mathrm{R}-5,65-67$ & 6.7 & 0.27 & 1.27 & $\mathrm{R}$ \\
\hline $2 \mathrm{R}-4,67-71$ & 13.9 & 0.30 & 1.59 & $\mathrm{R}$ \\
\hline $3 R-4,73-75$ & 22.9 & 0.31 & 1.22 & $\hat{R}$ \\
\hline $4 R-4,45-47$ & 32.0 & 0.30 & 2.13 & $\hat{R}$ \\
\hline $7 \mathrm{R}-4,69-73$ & 61.3 & 0.26 & 1.69 & $\mathrm{R}$ \\
\hline $10 \mathrm{R}-4,78-82$ & 88.9 & $0.17^{\mathrm{c}}$ & 1.33 & $\begin{array}{l}\hat{R} \\
\mathrm{R}\end{array}$ \\
\hline $11 \mathrm{R}-1,145-150$ & 96.1 & n.d. & 1.00 & R \\
\hline \multicolumn{5}{|l|}{ 139-855D- } \\
\hline $4 \mathrm{R}-1,0-5$ & 104.3 & 0.13 & 1.52 & - \\
\hline 4R-CC & 108.5 & 0.17 & 1.75 & - \\
\hline \multicolumn{5}{|l|}{$139-856 \mathrm{~A}-$} \\
\hline $1 \mathrm{H}-1,0-1$ & 0 & 0.33 & 5.56 & F \\
\hline $1 \mathrm{H}-2,35-37$ & 1.9 & $0.31^{\mathrm{c}}$ & 1.03 & $\mathrm{~F}$ \\
\hline $2 \mathrm{H}-3,83-85$ & 6.3 & $0.36^{\mathrm{c}}$ & 1.05 & - \\
\hline $3 \mathrm{H}-2,67-71$ & 14.4 & $0.29^{\mathrm{c}}$ & 1.14 & $\mathrm{R}$ \\
\hline $4 \mathrm{H}-5,78-82$ & 28.5 & $0.29^{\mathrm{c}}$ & 1.06 & $\mathrm{R}$ \\
\hline $5 \mathrm{H}-2,63-67$ & 33.4 & $0.26^{\mathrm{c}}$ & 1.01 & - \\
\hline $5 \mathrm{H}-\mathrm{CC}$ & 40.7 & 0.26 & 1.20 & - \\
\hline $6 \mathrm{H}-4,49-53$ & 45.7 & n.d. & 1.00 & - \\
\hline $7 \mathrm{H}-4,57-61$ & 55.3 & $0.28^{\mathrm{c}}$ & 1.05 & - \\
\hline \multicolumn{5}{|l|}{ 139-856B- } \\
\hline $1 \mathrm{H}-\mathrm{CC}$ & 1.8 & n.d. & 1.00 & $\mathrm{R}$ \\
\hline $2 \mathrm{H}-6,123-127$ & 10.6 & n.d. & 1.00 & - \\
\hline $2 \mathrm{H}-\mathrm{CC}$ & 11.8 & n.d. & 1.00 & - \\
\hline $4 \mathrm{H}-5,102-104$ & 27.8 & n.d. & 1.00 & - \\
\hline $5 \mathrm{H}-4,34-39$ & 35.2 & n.d. & 1.00 & - \\
\hline $7 \mathrm{H}-2,119-121$ & 52.0 & n.d. & 1.00 & - \\
\hline \multicolumn{5}{|l|}{ 139-857A- } \\
\hline $1 \mathrm{H}-1,0-1$ & 1.9 & 0.28 & 1.72 & C \\
\hline $1 \mathrm{H}-1,5-7$ & 2.0 & 0.22 & 1.12 & $\mathrm{C}$ \\
\hline $2 \mathrm{H}-2,73-75$ & 13.6 & 0.15 & 1.02 & c \\
\hline $2 \mathrm{H}-\mathrm{CC}$ & 20.9 & 0.29 & 1.85 & $\mathrm{~F}$ \\
\hline $3 \mathrm{H}-\mathrm{CC}$ & 21.9 & 0.26 & 1.54 & $\mathrm{R}$ \\
\hline $4 \mathrm{H}-2,86-90$ & 24.3 & 0.31 & 1.37 & $\mathrm{R}$ \\
\hline $4 \mathrm{H}-\mathrm{CC}$ & 31.4 & 0.29 & 1.89 & F \\
\hline $5 \mathrm{H}-\mathrm{CC}$ & 40.9 & 0.26 & 1.64 & $\mathrm{~F}$ \\
\hline $6 \mathrm{H}-4,54-58$ & 46.0 & 0.30 & 1.12 & $\mathrm{R}$ \\
\hline $7 \mathrm{H}-3,81-85$ & 54.2 & $0.26^{\mathrm{c}}$ & 1.01 & $\hat{F}$ \\
\hline $8 \mathrm{H}-2,95-99$ & 62.4 & $0.18^{\mathrm{c}}$ & 1.02 & $\mathrm{R}$ \\
\hline $9 \mathrm{H}-3,86-90$ & 73.3 & $0.18^{\mathrm{c}}$ & 1.05 & $\mathrm{~F}$ \\
\hline $10 \mathrm{H}-2,79-81$ & 81.2 & $0.26^{\mathrm{c}}$ & 1.01 & $\mathrm{R}$ \\
\hline $10 \mathrm{H}-6,26-28$ & 86.7 & n.d. & 1.00 & $\mathrm{R}$ \\
\hline $10 \mathrm{H}-6,28-30$ & 86.7 & n.d. & 1.00 & $\mathrm{R}$ \\
\hline $13 \mathrm{X}-\mathrm{CC}$ & 111.2 & n.d. & 1.00 & $\hat{R}$ \\
\hline \multicolumn{5}{|l|}{$139-857 \mathrm{C}-$} \\
\hline $2 \mathrm{R}-1,63-67$ & 57.2 & 0.17 & 1.14 & F \\
\hline $3 \mathrm{R}-1,90-92$ & 67.4 & & 1.01 & $\mathrm{~F}$ \\
\hline $3 R-3,38-40$ & 69.9 & $0.17^{\mathrm{c}}$ & 1.02 & $\mathrm{~F}$ \\
\hline $5 \mathrm{R}-1,4-8$ & 82.2 & $0.32^{\mathrm{C}}$ & 1.01 & $\mathrm{~F}$ \\
\hline $6 \mathrm{R}-1,66-68$ & 86.8 & n.d. & 1.00 & $\mathrm{R}$ \\
\hline 9R-CC & 124.1 & n.d. & 1.00 & $\mathrm{R}$ \\
\hline $14 \mathrm{R}-3,0-3$ & 165.8 & n.d. & 1.00 & $\hat{R}$ \\
\hline $28 \mathrm{R}-3,0-15$ & 296.8 & n.d. & 1.00 & \\
\hline
\end{tabular}

\begin{tabular}{|c|c|c|c|c|}
\hline $\begin{array}{l}\text { Core, section, } \\
\text { interval }(\mathrm{cm})\end{array}$ & $\begin{array}{l}\text { Depth } \\
\text { (mbsf) }\end{array}$ & $\mathrm{U}_{37}^{\mathrm{K}}$ & $\frac{\left[n-\mathrm{C}_{29} \mathrm{H}_{60}\right]+[\Sigma 37: \mathrm{i}]^{\mathrm{a}}}{\left[n-\mathrm{C}_{29} \mathrm{H}_{60}\right]}$ & $\begin{array}{l}\text { Emiliania } \\
\text { huxleyi }^{\mathrm{b}} \\
\text { presence }^{\mathrm{b}}\end{array}$ \\
\hline $\begin{array}{l}31 \mathrm{R}-2,102-105 \\
43 \mathrm{R}-1,66-70\end{array}$ & $\begin{array}{l}325.2 \\
385.4\end{array}$ & $\begin{array}{l}\text { n.d. } \\
\text { n.d. }\end{array}$ & $\begin{array}{l}1.00 \\
1.00\end{array}$ & $\underline{R}$ \\
\hline $\begin{array}{l}139-858 \mathrm{~A}- \\
1 \mathrm{H}-1,3-4 \\
1 \mathrm{H}-1,5-7 \\
1 \mathrm{H}-1,53-54 \\
1 \mathrm{H}-1,57-58 \\
1 \mathrm{H}-1,75-76 \\
1 \mathrm{H}-1,81-83 \\
1 \mathrm{H}-1,130-131 \\
1 \mathrm{H}-1,149-150 \\
1 \mathrm{H}-2,12-14 \\
2 \mathrm{H}-1,34-36 \\
2 \mathrm{H}-2,85-87 \\
2 \mathrm{H}-3,45-49 \\
2 \mathrm{H}-5,28-33 \\
2 \mathrm{H}-\mathrm{CC} \\
3 \mathrm{H}-3,81-85 \\
3 \mathrm{H}-6,0-1 \\
4 \mathrm{H}-2,0-1 \\
4 \mathrm{H}-4,52-56 \\
5 \mathrm{H}-5,0-3 \\
6 \mathrm{H}-3,55-56 \\
7 \mathrm{H}-\mathrm{CC} \\
11 \mathrm{X}-\mathrm{CC}\end{array}$ & $\begin{array}{r}0.0 \\
0.1 \\
0.5 \\
0.6 \\
0.7 \\
0.8 \\
1.3 \\
1.5 \\
1.6 \\
2.8 \\
4.8 \\
5.9 \\
8.7 \\
12.1 \\
15.8 \\
19.4 \\
22.9 \\
26.5 \\
36.9 \\
44.0 \\
58.9 \\
81.6\end{array}$ & $\begin{array}{l}0.36 \\
0.34 \\
0.30 \\
0.39 \\
0.24 \\
0.26 \\
0.34 \\
\text { n.d. } \\
0.24 \\
0.18^{\mathrm{c}} \\
0.34 \\
0.23 \\
0.17^{\mathrm{c}} \\
0.32 \\
0.34^{\mathrm{c}} \\
\text { n.d. } \\
\text { n.d. } \\
\text { n.d. } \\
\text { n.d. } \\
\text { n.d. } \\
\text { n.d. } \\
\text { n.d. }\end{array}$ & $\begin{array}{l}4.00 \\
2.13 \\
2.33 \\
1.27 \\
1.89 \\
1.39 \\
1.18 \\
1.00 \\
1.14 \\
1.11 \\
1.19 \\
1.25 \\
1.15 \\
2.56 \\
1.02 \\
1.00 \\
1.00 \\
1.00 \\
1.00 \\
1.00 \\
1.00 \\
1.00\end{array}$ & $\begin{array}{l}F \\
F \\
F \\
F \\
F \\
F \\
F \\
F \\
F \\
F \\
F \\
F \\
F \\
R \\
R \\
R \\
F \\
\\
Z \\
\\
\end{array}$ \\
\hline $\begin{array}{l}139-858 \mathrm{~B}- \\
1 \mathrm{H}-1,17-18 \\
1 \mathrm{H}-1,48-52 \\
1 \mathrm{H}-2,31-32 \\
1 \mathrm{H}-2,42-44 \\
1 \mathrm{H}-2,130-131 \\
1 \mathrm{H}-\mathrm{CC} \\
2 \mathrm{H}-\mathrm{CC} \\
5 \mathrm{H}-2,112-113\end{array}$ & $\begin{array}{r}0.2 \\
0.5 \\
1.8 \\
1.9 \\
2.8 \\
7.2 \\
16.7 \\
26.5\end{array}$ & $\begin{array}{l}0.33^{\mathrm{c}} \\
0.31^{\mathrm{c}} \\
0.34^{\mathrm{c}} \\
0.39^{\mathrm{c}} \\
0.29 \\
\text { n.d. } \\
\text { n.d. } \\
\text { n.d. }\end{array}$ & $\begin{array}{l}1.18 \\
1.20 \\
1.14 \\
1.06 \\
1.56 \\
1.00 \\
1.00 \\
1.00\end{array}$ & $\begin{array}{l}\mathrm{R} \\
\mathrm{R} \\
\mathrm{C} \\
\mathrm{C} \\
\mathrm{F} \\
- \\
\\
-\end{array}$ \\
\hline $\begin{array}{l}139-858 \mathrm{C}- \\
1 \mathrm{H}-1,22-26 \\
1 \mathrm{H}-2,0-5 \\
1 \mathrm{H}-2,42-46 \\
1 \mathrm{H}-3,21-25 \\
2 \mathrm{H}-1,42-44 \\
2 \mathrm{H}-5,71-73 \\
2 \mathrm{H}-\mathrm{CC} \\
3 \mathrm{H}-2,53-54 \\
3 \mathrm{H}-\mathrm{CC}\end{array}$ & $\begin{array}{r}0.3 \\
1.5 \\
2.0 \\
3.3 \\
3.9 \\
10.2 \\
13.0 \\
15.0 \\
22.5\end{array}$ & $\begin{array}{l}0.35 \\
0.27 \\
0.26^{\mathrm{c}} \\
0.63^{\mathrm{c}} \\
0.39^{\mathrm{c}} \\
\text { n.d. } \\
\text { n.d. } \\
\text { n.d. } \\
\text { n.d. }\end{array}$ & $\begin{array}{l}1.67 \\
1.16 \\
1.02 \\
1.01 \\
1.03 \\
1.00 \\
1.00 \\
1.00 \\
1.00\end{array}$ & $\begin{array}{l}\mathrm{R} \\
\mathrm{R} \\
\mathrm{R} \\
\mathrm{C} \\
\mathrm{C} \\
\mathrm{F} \\
\mathrm{F} \\
-\end{array}$ \\
\hline $\begin{array}{l}139-858 \mathrm{D}- \\
1 \mathrm{H}-1,0-1 \\
1 \mathrm{H}-1,145-150 \\
1 \mathrm{H}-3,145-150 \\
1 \mathrm{H}-4,145-150 \\
1 \mathrm{H}-5,145-150 \\
6 \mathrm{X}-1,96-105\end{array}$ & $\begin{array}{r}0.0 \\
1.5 \\
4.5 \\
6.0 \\
7.5 \\
29.8\end{array}$ & $\begin{array}{l}0.36 \\
0.36 \\
0.41^{\mathrm{c}} \\
\text { n.d. } \\
\text { n.d. } \\
\text { n.d. }\end{array}$ & $\begin{array}{l}1.82 \\
1.14 \\
1.01 \\
1.00 \\
1.00 \\
1.00\end{array}$ & $\begin{array}{l}\mathrm{R} \\
\mathrm{C} \\
\mathrm{R} \\
\mathrm{R} \\
\mathrm{C} \\
\end{array}$ \\
\hline $\begin{array}{l}\text { Seabed sediment, un- } \\
\text { altered } \\
\text { Hydrous pyrolysis, } \\
200^{\circ} \mathrm{C} \\
\text { Hydrous pyrolysis, } \\
250^{\circ} \mathrm{C}\end{array}$ & 0 & 0.69 & 1.51 & \\
\hline
\end{tabular}

Note: n.d. $=$ not detected.

${ }^{\text {a }}$ Ratio of relative concentrations of the sum of $\mathrm{C}_{37: 2}+\mathrm{C}_{37: 3}$ alkenones to $n$-nonacosane. ${ }^{\mathrm{b}} \mathrm{C}=$ common, $\mathrm{F}=$ few, $\mathrm{R}=$ rare,$-=$ none found

${ }^{c}$ Low concentration.

\section{Site 856}

The data for the upper $30 \mathrm{mbsf}$ of Hole $856 \mathrm{~A}, 200 \mathrm{~m}$ north of the relict sulfide deposit, range from 0.31 to 0.36 , showing conditions that are $11.3^{\circ}-12.5^{\circ} \mathrm{C}$, i.e., warmer than those in the deeper sections where the range is $0.26-0.29$, equivalent to $10.1^{\circ}-10.8^{\circ} \mathrm{C}$ (Fig. 3A). The values in the upper $30 \mathrm{mbsf}$ are slightly lower than the range of values observed in sediment trap materials and surficial sediments from locations at $3^{\circ}-6^{\circ}$ latitude farther south $\left(U_{37}^{K}: 0.35-0.43\right)$ (Prahl et al., 1988 , 1993). Examples of temperatures derived from this ratio measured in surficial sediments from the more tropical regions such as Site 658 in the eastern equatorial Atlantic Ocean (Poynter et al., 1989), Site 686 on the Peru Margin (Farrimond et al., 1990a, 1990b), and Guaymas Basin (sample AII-112-29, PC1, which was used for hydrous pyrolysis) are also shown in Figure 3B for reference. The alkenone/alkane plot for Hole 856A (Fig. 4B) shows a high value at the seafloor and decreases to trace values with increasing depth below seafloor. The alkenones were not detectable in the bitumen extracts of sediments from Hole $856 \mathrm{~B}$, because this hole is in a relict vent system and thus probably was exposed to high temperatures throughout the section (Table 1). 
Table 2. Summary of temperatures below seafloor, depths at which alkenones disappear, and inferred upper ocean paleotemperatures.

\begin{tabular}{cccc}
\hline Present in-situ & $\begin{array}{c}\text { temperature } \\
\text { at depth where } \\
\text { alkenones disappear } \\
\left({ }^{\circ} \mathrm{C}\right)^{\mathrm{a}}\end{array}$ & $\begin{array}{c}\text { Depth of } 200^{\circ} \mathrm{C} \\
\text { isotherm } \\
(\mathrm{mbsf})^{\mathrm{b}}\end{array}$ & $\begin{array}{c}\text { Paleotemperature } \\
\text { for organic matter } \\
\text { synthesis }\left({ }^{\circ} \mathrm{C}\right)\end{array}$ \\
\hline $855 \mathrm{~A}$ & - & $>60$ & $11-15$ \\
$855 \mathrm{~B}$ & - & $30-40$ & 12 \\
$855 \mathrm{C}$ & 26 & $>96$ & $8-11$ \\
$855 \mathrm{D}$ & 20 & $>110$ & $7-8$ \\
$856 \mathrm{~A}$ & 30 & 45 & $10-12.5$ \\
$856 \mathrm{~B}$ & 20 & 0 & -1.5 \\
$857 \mathrm{~A}$ & - & 85 & $7.5-11$ \\
$857 \mathrm{C}$ & 30 & 85 & $8-11.5$ \\
$858 \mathrm{~A}$ & 5,35 & $1.5,16$ & $8-13$ \\
$858 \mathrm{~B}$ & $30-80$ & $3-7$ & $11-13$ \\
$858 \mathrm{C}$ & $40-50$ & $4-10$ & $10-13$ \\
$858 \mathrm{D}$ & 50 & 5 & $12.5-14$ \\
Average & & & 10.7 \\
\hline
\end{tabular}

${ }^{\text {a }}$ Measured temperatures as reported by Davis, Mottl, Fisher, et al. (1992).

${ }^{b}$ Hydrous pyrolysis of unaltered sediments showed that alkenones disappear just above $200^{\circ} \mathrm{C}$ over a one-day period.
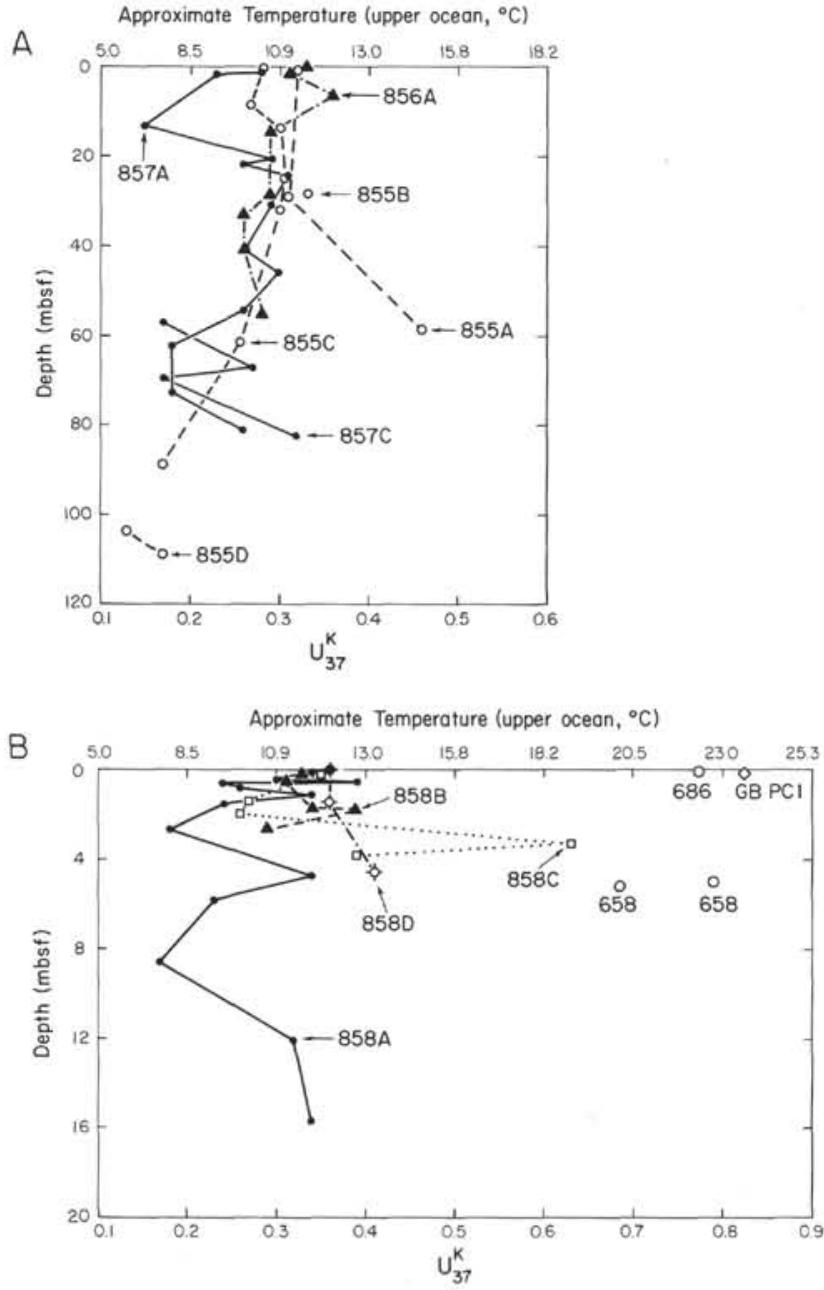

Figure 3. $\mathrm{C}_{37}$ alkenone parameter $\left(\mathrm{U}_{37}^{\mathrm{K}}\right)$ and temperature estimate of the ocean surface water vs. depth below seafloor. A. Holes $855 \mathrm{~A}, 855 \mathrm{~B}, 855 \mathrm{C}, 855 \mathrm{D}$, $856 \mathrm{~A}, 857 \mathrm{~A}$, and $857 \mathrm{C}$. B. Holes $858 \mathrm{~A}, 858 \mathrm{~B}, 858 \mathrm{C}$, and $858 \mathrm{D}$. Other more tropical sites are also shown for comparison ( $\mathrm{GB}=$ Guaymas Basin).

\section{Site 857}

The alkenones were detectable in the bitumen extracts of sediments from Holes $857 \mathrm{~A}$ and $857 \mathrm{C}$ to a depth of about $80 \mathrm{mbsf}$ but not in the deeper sections (Table 1). This is illustrated by the alkenone/alkane plots (Fig. 4C) with values in the range of 1.0 to 1.2. The presence of alkenones to that depth in these holes parallels the occurrence of Emiliania huxleyi (Table 1; Davis, Mottl, Fisher, et al., 1992), although the molecular fossils disappear before the fossil tests, probably due to decomposition of the alkenones with increasing temperatures. Because the alkenones are not stable under significant thermal stress, their distribution is consistent with the current thermal regime (Davis, Mottl, Fisher, et al., 1992; Table 2). The samples from the upper 50 mbsf show slightly warmer sea-surface conditions $\left(9^{\circ}-11^{\circ} \mathrm{C}\right.$, with a $\mathrm{U}_{37}^{\mathrm{K}}$ range of $0.22-0.31$, Fig. 3A), except for Sample 139-857 A-2H-2, $73-75 \mathrm{~cm}$, at $13.6 \mathrm{mbsf}$, which has a $\mathrm{U}_{37}^{\mathrm{R}}=0.15$, equivalent to $7.5^{\circ} \mathrm{C}$. The deeper sections for both Holes $857 \mathrm{~A}$ and $857 \mathrm{C}$ have $\mathrm{U}_{37}^{\mathrm{K}}=0.17-$ 0.32 , equivalent to an average temperature of $9.7^{\circ} \mathrm{C}$. The $\mathrm{U}_{37}^{\mathrm{K}}$ in the depth interval below 55 mbsf (Fig. 3A) is variable due to the low alkenone content, reflecting high thermal stress.

\section{Site 858}

The alkenones were detectable only in the bitumen extracts of sediments from Holes $858 \mathrm{~A}, 858 \mathrm{~B}, 858 \mathrm{C}$, and $858 \mathrm{D}$ to a maximum depth of $16 \mathrm{mbsf}$, and generally only in the surficial sections (Table 1, Fig. 3B). Their presence in these holes parallels the occurrence of Emiliania huxleyi (Table 1; Davis, Mottl, Fisher, et al., 1992), but here, too, the molecular fossils disappear before the fossil tests, due to higher in-situ temperatures (Table 2). The thermal instability of these alkenones makes their distribution a useful temperature indicator. This is reflected in the alkenone/alkane ratios given in Table 1 and plotted in Figure 4D-F. The alkenones decrease rapidly with increasing depth below seafloor (values of 1.0) with the exception of a couple of concentration spikes for Holes 858A and 858B (Fig. 4D-F). The $\mathrm{U}_{37}^{\mathrm{K}}$ values for Hole $858 \mathrm{~A}$ range from 0.17 to 0.39 , which are representative of sea-surface temperatures of $8^{\circ}-13.2^{\circ} \mathrm{C}$ as observed for the other sites of this leg. The $U_{37}^{K}$ values for Holes $858 \mathrm{~B}, 858 \mathrm{C}$, and $858 \mathrm{D}$ average 0.32 , excluding the samples with trace concentrations of alkenones, which correspond to about $11.5^{\circ} \mathrm{C}$. The $U_{37}^{K}$ values in the depth intervals below 2 mbsf (below 8 mbsf in Hole 858A) are variable due to low alkenone concentrations, a consequence of high heat flow and hydrothermal alteration.

\section{CONCLUSIONS}

The $\mathrm{C}_{37}$ alkenones are present in the shallow sections of most holes drilled during Leg 139. They indicate a range of growth temperatures during prymnesiophyte synthesis within surface waters of $7^{\circ}-15^{\circ} \mathrm{C}$, with an average of $10.7^{\circ} \mathrm{C}$ (Table 2).

The depth below seafloor of a $200^{\circ} \mathrm{C}$ isotherm, that is, the depth where the in-situ temperature could have approached $200^{\circ} \mathrm{C}$ for a brief time, is estimated for each hole based on the disappearance of the alkenones (Table 2, Fig. 4). The present measured temperatures at these depths (Table 2) are $<80^{\circ} \mathrm{C}$, indicating that alkenone alteration may be tied to lower temperatures over longer time. At Site 855 , the recharge zone of the hydrothermal system and location of the reference holes, this depth correlates well with the distance from the fault scarp (i.e., Hole 855B, 30-40 mbsf; Hole 855A, >60 mbsf; and Holes $855 \mathrm{C}$ and $855 \mathrm{D}, 96$ and 110 mbsf, respectively). At Site 856 only Hole $856 \mathrm{~A}$, on Bent Hill, yielded alkenones to $45 \mathrm{mbsf}$; the other holes analyzed had no alkenones. This confirms the relict high temperatures at this site about $200 \mathrm{~m}$ north from Holes $856 \mathrm{~B}-856 \mathrm{D}$. In Holes $857 \mathrm{~A}$ and $857 \mathrm{C}$ the alkenones disappear at $85 \mathrm{mbsf}$, indicating horizontal isotherms across the 200-m distance between the holes. This is consistent with the interpretation that a hydrothermal reservoir lies under this site, although the surface heat flow is different between the two holes. Site 858 is in the active vent area. Hole $858 \mathrm{~A}$, located 

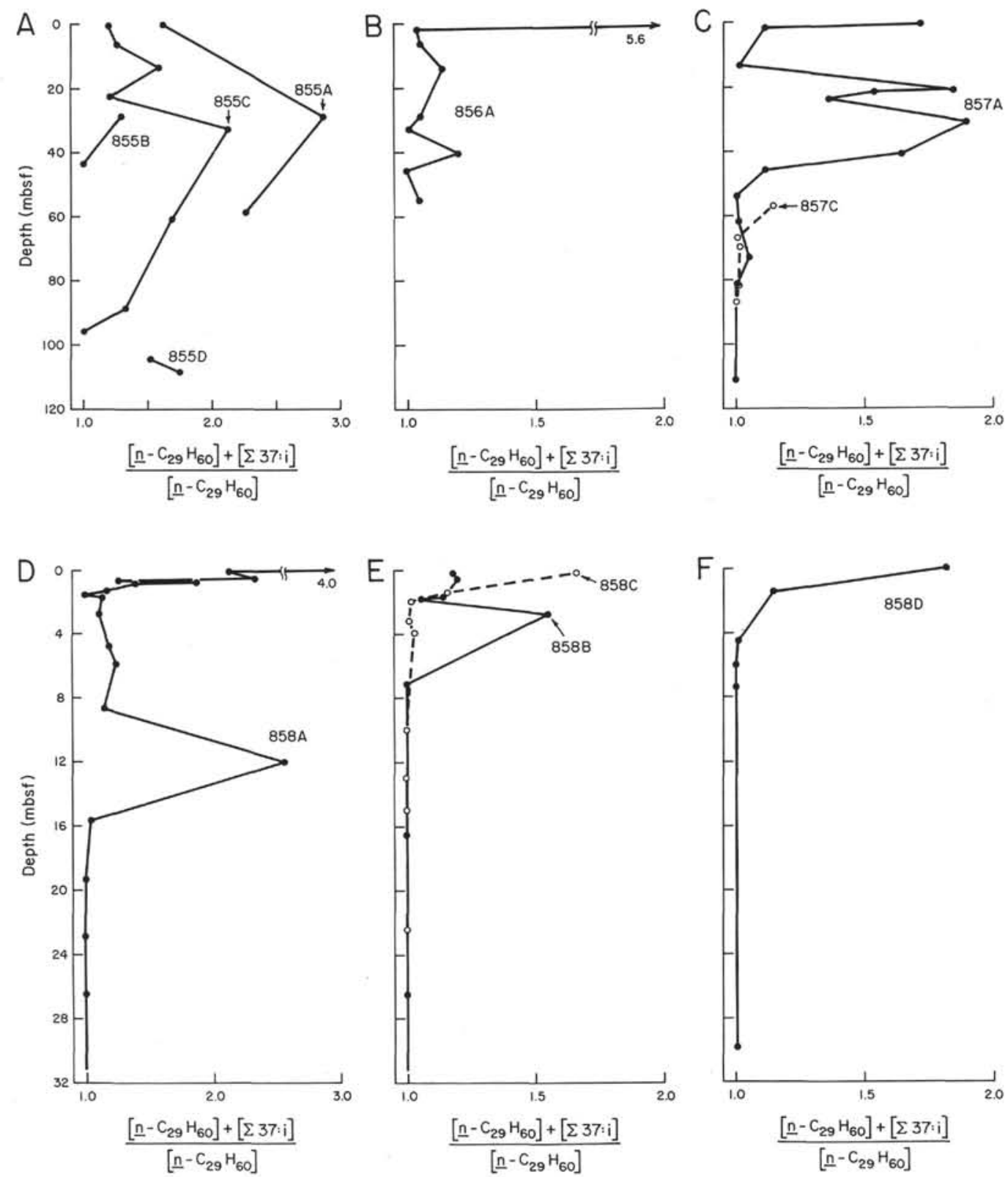

Figure 4. Alkenone concentration parameter $\left(\frac{\left[n-\mathrm{C}_{29} \mathrm{H}_{60}\right]+[\Sigma 37: \mathrm{i}]}{\left[n-\mathrm{C}_{29} \mathrm{H}_{60}\right]}\right)$ vs. depth below seafloor. A. Holes $855 \mathrm{~A}-855 \mathrm{D}$. B. Hole $856 \mathrm{~A}$. C. Holes $857 \mathrm{~A}$ and $857 \mathrm{C}$. D. Hole 858A. E. Holes 858B and 858C. F. Hole 858D.

$\sim 200 \mathrm{~m}$ off center, had a hot fluid incursion at $1.5 \mathrm{mbsf}$ and the $200^{\circ} \mathrm{C}$ isotherm is at about $16 \mathrm{mbsf}$. Hole $858 \mathrm{C}$ is at the edge of the vent area and the alkenones disappear in the 4-10 mbsf interval. Holes 858B and $858 \mathrm{D}$ are in the center of the vent area and the alkenones are depleted at the shallowest depths, which are 3-7 and $5 \mathrm{mbsf}$, respectively. The consistent fit of the disappearance of the alkenones with the observed heat flows makes these alkenones useful thermal probes.

\section{ACKNOWLEDGMENTS}

Financial support from the National Science Foundation, Division of Ocean Sciences (Grant OCE-9002366), and from the NSF and JOI, Inc., U.S. Science Support Program of the Ocean Drilling Program is gratefully acknowledged. We thank Dr. Simon Brassell and an anonymous reviewer for their comments and suggestions which greatly improved this paper.
The U.S. Science Program associated with the Ocean Drilling Program is sponsored by the National Science Foundation and the Joint Oceanographic Institutions, Inc. Any opinions, findings, and conclusions or recommendations expressed in this publication are those of the authors and do not necessarily reflect the views of the National Science Foundation, the Joint Oceanographic Institutions, Inc., or Texas A\&M University.

\section{REFERENCES}

Brassell, S.C., Eglinton, G., Marlowe, I.T., Pflaumann, U., and Sarntheim, M., 1986. Molecular stratigraphy: a new tool for climatic assessment. Nature, 320:129-133.

- Abbreviations for names of organizations and publications in ODP reference lists follow the style given in Chemical Abstracts Service Source Index (published by American Chemical Society). 
Davis, E.E., Mottl, M.J., Fisher, A.T., et al., 1992. Proc. ODP, Init. Repts., 139: College Station, TX (Ocean Drilling Program).

Farrimond, P., Poynter, J.G., and Eglinton, G., 1990a. Molecular composition of sedimentary lipids off the Peru margin, Leg 112. In Suess, E., von Huene, R., et al., Proc. ODP, Sci. Results, 112: College Station, TX (Ocean Drilling Program), 539-546.

1990b. A molecular stratigraphic study of Peru Margin sediments, Hole 686B, Leg 112. In Suess, E., von Huene, R., et al., Proc. ODP, Sci. Results, 112: College Station, TX (Ocean Drilling Program), 547-553.

Kawka, O.E., and Simoneit, B.R.T., 1987. Survey of hydrothermally-generated petroleums from the Guaymas Basin spreading center. Org. Geochem., 11:311-328.

Leif, R.N., Simoneit, B.R.T., and Kvenvolden, K.A., 1991. Simulation of hydrothermal petroleum generation by laboratory hydrous pyrolysis. In Manning, D.A.C. (Ed.), Organic Geochemistry: Advances and Applications in the Natural Environment: Manchester (Manchester Univ. Press), 300-303.

, 1992. Hydrous pyrolysis of $n-\mathrm{C}_{32} \mathrm{H}_{66}$ in the presence and absence of inorganic components. Am. Chem. Soc., Div. Fuel Chem., 204th Nat. Meet., Preprints, 37:1748-1753.

Marlowe, I.T., Brassell, S.C., Eglinton, G., and Green, J.C., 1984. Long-chain unsaturated ketones and esters in living algae and marine sediments. In Schenck, P.A., de Leeuw, J.W., and Lijmbach, G.W.M. (Eds.), Advances in Organic Geochemistry 1983. Org. Geochem., 6:135-141.

1990. Long chain alkenones and alkyl alkenoates and the fossil coccolith record of marine sediments. Chem. Geol., 88:349-375.

Peter, J.M., Peltonen, P., Scott, S.D., Simoneit, B.R.T., and Kawka, O.E., 1991. ${ }^{14} \mathrm{C}$ ages of hydrothermal petroleum and carbonate in Guaymas Basin, Gulf of California: implications for oil generation, expulsion and migration. Geology, 19:253-256.

Poynter, J.G., Farrimond, P., Brassell, S.C., and Eglinton, G., 1989. Molecular stratigraphic study of sediments from Holes 658A and 660A, Leg 108. In Ruddiman, W., Sarnthein, M., et al., Proc. ODP, Sci. Results, 108: College Station, TX (Ocean Drilling Program), 387-394.

Prahl, F.G., Collier, R.B., Dymond, J., Lyle, M., and Sparrow, M., 1993. A biomarker perspective on Prymnesiophyte productivity and life history in the northeast Pacific Ocean. Deep-Sea Res. Part A, 40:2061-2076.
Prahl, F.G., Muehlhausen, A., and Zahnle, D., 1988. Further evaluation of long-chain alkenones as indicators of paleoceanographic conditions. Geochim. Cosmochim. Acta, 52:2303-2310.

Prahl, F.G., and Wakeham, S.G., 1987. Calibration of unsaturation patterns in long-chain ketone compositions for paleotemperature assessment. Nature, 330:367-369.

Rechka, J.A., and Maxwell, J.R., 1988a. Characterisation of alkenone temperature indicators in sediments and organisms. In Mattavelli, L., and Novelli, L. (Eds.), Advances in Organic Geochemistry 1987. Org. Geochem., 13:727-734.

1988b. Unusual long chain ketones of algal origin. Tetrahedron Lett., 29:2599-2600.

Sikes, E.L., and Volkman, J.K., 1993. Calibration of alkenone unsaturation ratios $\left(\mathrm{U}_{37}^{\mathrm{K}}\right)$ for paleotemperature estimation in cold polar waters. Geochim. Cosmochim. Acta, 57:1883-1889.

Simoneit, B.R.T., 1990. Petroleum generation-an easy and widespread process in hydrothermal systems: an overview. In Simoneit, B.R.T., Organic Matter in Hydrothermal Systems-Petroleum Generation, Migration and Biogeochemistry. Appl. Geochem., 5:3-15.

, 1991. Hydrothermal effects on recent diatomaceous sediments in Guaymas Basin-generation, migration and deposition of petroleum. In Dauphin, J.P., and Simoneit, B.R.T., The Gulf and Peninsular Province of the Californias. AAPG Mem., 47:793-825.

Simoneit, B.R.T., Kawka, O.E., and Wang, G.-M., 1992. Biomarker maturation in contemporary hydrothermal systems, alteration of immature organic matter in zero geological time. In Moldowan, J.M., Albrecht, P. and Philp, R.P. (Eds.), Biological Markers in Sediments and Petroleum: Englewood Cliffs, NJ (Prentice Hall), 124-141.

Volkman, J.K., Eglinton, G., Corner, E.D.S., and Forsberg, T.E.V., 1980. Long-chain alkenes and alkenones in the marine coccolithophorid Emiliania huxleyi. Phytochemistry, 19:2619-2622.

Date of initial receipt: 11 January 1993

Date of acceptance: 23 August 1993

Ms 139SR-239 